JSIP: Jurnal Studi Ilmu Pemerintahan

Volume 2, No 1 Februari 2021

ISSN: 2722-7405

\title{
PROBLEMATIKA DEMOKRASI PRESIDENSIL PASCA PERUBAHAN UNDANG-UNDANG DASAR
}

\author{
Abdul Aziz Zaini ${ }^{1}$ \\ Maturidi2 \\ ${ }^{1}$ Mahasiswa Magister Ilmu Syariah Universitas Islam Negeri Sunan Kalijaga Yogyakarta \\ ${ }^{2}$ Mahasiswa Magister Interdisciplinary Islamic Studies Universitas Islam Negeri Sunan Kalijaga \\ Yogyakarta \\ Abdulazizzaaini.dizky@gmail.com

\begin{tabular}{|c|c|}
\hline Article Info & \\
\hline $\begin{array}{l}\text { Kata Kunci: } \\
\text { Demokrasi }^{1} \text {, } \\
\text { Presidensil', } \\
\text { Perubahan } \\
\text { Undang-Undang } \\
\text { Dasar }{ }^{3} \text {. }\end{array}$ & $\begin{array}{l}\text { Abstract After the changes to the Constitution (UUD), Indonesia, which } \\
\text { previously adopted a parliamentary system of government, turned into a } \\
\text { presidential system of government, which still has many democratic problems. } \\
\text { These changes also have implications for changes in the government system, } \\
\text { including: The President is directly elected by the people through general } \\
\text { elections, the Position of the People's Consultative Assembly (MPR) which was } \\
\text { previously the highest state institution to be a high state institution, } \\
\text { Strengthening the role and authority of the House of Representatives (DPR) in } \\
\text { the field of legislation and oversight of the executive. One of the provisions } \\
\text { which strongly indicates the strength of the presidential system in the } 1945 \\
\text { Constitution is in Article 7C, which states that the President cannot freeze and / } \\
\text { or dissolve the DPR. Historically, many have argued that this article was raised } \\
\text { as a response to the statement of former President Abdurrahman Wahid, who } \\
\text { had issued a decree to dissolve the DPR when he served as President of the } \\
\text { Republic of Indonesia. }\end{array}$ \\
\hline
\end{tabular}

Abstrak Pasca perubahan Undang-Undang Dasar (UUD), Indonesia yang sebelumnya menganut sistem pemerintahan parlementer berubah menjadi sistem pemerintahan presidensil masih banyak mengalami problem demokrasi. Perubahan tersebut turut berimplikasi kepada perubahan sistem pemerintahan, diantaranya yaitu: Presiden dipilih langsung oleh rakyat melalui pemilihan umum, Kedudukan Majelis Permusyawaratan Rakyat (MPR) yang sebelumnya lembaga tertinggi negara menjadi lembaga tinggi negara, Penguatan peran dan kewenangan Dewan Perwakilan Rakyat (DPR) dalam bidang legislasi dan pengawasan terhadap eksekutif. Salah satu ketentuan yang sangat menandakan kuatnya sistem presidensil dalam UUD 1945 pada Pasal 7C, yang menyatakan Presiden tidak dapat membekukan dan/atau membubarkan DPR. Secara historis, banyak pihak berpendapat bahwa pasal ini dimunculkan sebagai respon terhadap pernyataan Mantan Presiden Abdurrahman Wahid yang pernah mengeluarkan Dekrit untuk membubarkan DPR pada saat beliau menjabat sebagai Presiden Republik Indonesia.

\section{Pengantar}

Indonesia merupakan negara dengan sistem pemerintahan Presidensial. Hal ini didasarkan pada kesepakatan pendiri bangsa (founding father) dalam sidang Badan Penyelidik Usaha Persiapan Kemerdekaan (BPUPK) pada 29 Mei- 1 Juni dan 10-17 Juli 1945. Dalam hal ini Soepomo memiliki andil yang sangat besar dalam pembentukan pemerintahan Indonesia, karena 
gagasan yang dikeluarkannya itulah yang kemudian disetujui oleh peserta sidang (meskipun dengan perdebatan yang cukup rumit). Kemudian, meskipun dalam Pasal 4 ayat (1) UUD (Undang-undang Dasar) 1945 (sebelum amandemen) mengatakan dianutnya sistem pemerintahan presidensial,tetapi sistem yang diterapkan tetap mengandung ciri parlementernya, yaitu dengan adanya MPR yang berstatus sebagai lembaga tertinggi negara, tempat kemana presiden harus tunduk dan bertanggung jawab. Dengan kata lain sistem presidensial Indonesia tidak begitu tegas karena Presiden tidak dipilih langsung oleh rakyat (Yani 2018:249-58).

Namun, sejak konstitusi diamandemen, tepatnya amandemen ketiga presidensialisme di Indonesia sudah lebih murni. Dikatakan lebih murni karena Presiden menurut UUD Negara Republik Indonesia (NRI) 1945 sebelum amandemen, harus tunduk dan bertanggungjawab kepada MPR yang berwenang mengangkat dan memberhentikannya menurut UUD NRI 1945. Presiden menurut UUD NRI 1945 sebelum reformasi adalah mandataris MPR yang sewaktuwaktu dapat ditarik kembali oleh MPR sebagaimana mestinya. Sifat pertanggungjawaban kepada MPR ini justru memperlihatkan adanya unsur parlementer dalam sistem pemerintahan presidensial yang dianut. Namun setelah diamandemen Presiden dipilih langsung oleh rakyat dan tidak bertanggungjawab lagi kepada MPR sebagai mandataris MPR (Al-Arif 2015:13).

Dalam sejarah ketatanegaraan, Indonesia pernah mempraktikkan dua model sistem pemerintahan yaitu sistem presidensiil dan parlementer. Tahun 1945 sampai dengan tahun 1959 Indonesia menerapkan sistem pemerintahan parlementer dengan tiga konstitusi yang berbeda yaitu Undang-undang Dasar 1945 (1945 - 1949), Konstitusi Sementara Republik Indonesia Serikat (1949 - 1950) dan Undang-undang Dasar Sementara Republik Indonesia 1950 (1950 - 1959). Ketika kembali pada Undang-undang Dasar 1945 melalui Dekrit Presiden 5 Juli 1959, Indonesia memakai sistem pemerintahan presidensiil (Sa'adah 2019 :275). Reformasi yang terjadi di Indonesia pada tahun 1999 telah banyak menyebabkan perubahan di negeri ini, termasuk terhadap sistem dan praktik ketatanegaraan kita. Setiap gagasan akan perubahan tersebut sudah dituangkan dalam amanedemen I-IV UUD 1945. Perubahan-perubahan tersebut juga turut mempengaruhi struktur bagian-bagian negara sehingga tidak dapat lagi dijelaskan menurut cara berpikir lama (UUD 1945 pra amandemen). Banyak pokok-pokok pikiran baru yang diadopsi di dalam UUD 1945 itu. Empat diantaranya adalah (1) penegasan dianutnya cita demokrasi dan nomokrasi secara sekaligus dan saling melengkapi secara komplamenter; (2) pemisahan kekuasaan dan prinsip "check and balances" (3) pemurnian sistem pemerintah presidensil" (4) penguatan cita dan persatuan dan keragaman dalam wadah negara kesatuan Republik Indonesia (Sa'adah $2019: 276$ ).

Penegasan dianutnya cita demokrasi dan nomokrasi semakin menegaskan letak kedaulatan yang sebenarnya di tangan rakyat. UUD 1945 memberikan kedudukan yang mutlak kepada rakyat sebagai pemegang kekuasaan sesungguhnya. Kekuasaan bahkan idealnya diselenggarakan bersama-sama dengan rakyat. Dalam sistem UUD 1945, pelaksanaan kedaulatan rakyat itu disalurkan dan diselenggarakan menurut prosedur konstitusional yang ditetapkan dalam hukum dan konstitusi (constitutional democracy). Kedaulatan rakyat (democratie) Indonesia itu diselenggarakan secara langsung dan melalui sistem perwakilan. Penyaluran kedaulatan rakyat secara langsung diwujudkan melalui dilakukan melalui pemilihan umum untuk memilih anggota lembaga perwakilan dan memilih Presiden dan Wakil presiden. Di samping itu, kedaulatan rakyat dapat pula disalurkan setiap waktu melalui pelaksanaan hak dan kebebasan berpendapat, hak atas kebebasan pers, hak atas kebebasan informasi, hak atas kebebasan berorganisasi dan berserikat serta hak-hak asasi lainnya yang dijamin dalam UndangUndang Dasar (Sa'adah $2019: 276$ ).

Hal-hal tersebut pada akhirnya turut berimplikasi kepada perubahan sistem pemerintahan secara keseluruhan. Perubahan tersebut menyebabkan tiga hal yaitu: (a) Penegasan karakter presidensil dalam sistem pemerintahan Indonesia dengan menempatkan Presiden sebagai figur pilihan rakyat melalui pemilihan umum. (b) Perubahan kedudukan MPR dari lembaga tertinggi negara menjadi lembaga tinggi negara, dengan kewenangan yang sangat terbatas. (c) penguatan peran dan kewenangan DPR dalam bidang legislasi dan pengawasan terhadap eksekutif. Keinginan untuk menegaskan sistem presidensil sendiri sudah cukup lama. Hal ini disebabkan oleh kelemahan-kelemahan yang terdapat dalam UUD 1945. Meskipun dikatakan bahwa sistem pemerintahan Indonesia adalah sistem presidensil, namun pada kenyataannya sistem yang 
dianut adalah sistem campuran atau quasi presidensil. Sebagaimana dikatakan oleh Sri Soemantri bahwa sistem pemerintahan RI berdasarkan UUD 1945 memperlihatkan sekaligus segi-segi sistem pemerintahan presidensil dan sistem parlementer atau sistem campuran. Hal ini disebabkan oleh pengaturan dalam UUD 1945 sendiri yang menyatakan bahwa presiden merupakan mandataris MPR d(Bagir Manan 1999:41)an bertanggung jawab kepada MPR (Bagir Manan 1999:41).

\section{METODE PENELITIAN}

Penelitian ini merupakan penelitian kepustakaan (library research), sumber data penelitian ini diambil dari kepustakaan baik berupa buku, jurnal, majalah, artikel, dan hasil penelitian lain yang berkaitan dan sesuai dengan penelitian ini yang berjudul problematika demokrasi presidensil pasca perubahan UUD. Kemudian hasil penelitian tersebut akan diuraikan untuk menggungkapkan fakta-fakta penelitian secara jelas dan sistematis.

\section{HASIL DAN DISKUSI \\ Konsep Sistem Pemerintahan Presidensil}

Sebagaimana dikatakan Joeniarto bahwa, demokrasi modern dapat dibagai dalam tiga kelas, tergantung pada hubungan antara organ-organ pemerintahan yang mewakili tiga fungsi yang berbeda. Klasifikasi tersebut yaitu: (1) pemerintahan rakyat melalui perwakilan dengan sistem parlementer. (2) pemerintahan rakyat melalui perwakilan dengan sistem pemisahan kekuasaan. (3) pemerintahan rakyat melalui perwakilan dengan disertai pengawasan langsung oleh rakyat (Joeniarto 1982:66). Sedangkan Miriam Budiardjo membedakan kedua sistem ini kedalam dua kelompok, yaitu: Sistem parlementer (parliamentary executive) dan sistem presidensil dengan fixed executive atau non parliamentary executive (Miriam Budardjo 2009:301).

Dalam konteks Indonesia, salah satu kesepakatan dalam pelaksanaan amandemen UUD 1945 adalah tetap mempertahankan sistem presidensil, sekaligus menyempurnakan agar betulbetul memenuhi ciri-ciri umum sistem prsidensil (Jimly Asshiddiqie 2005b:10). Sistem Presidensil murni sebagai model pemerintahan Amerika Serikat pada hakekatnya mempunyai ciri-ciri yaitu: (a) Presiden adalah pemegang kekuasaan eksekutif tunggal. (b) Presiden adalah penyelenggara pemerintahan yang bertanggung jawab di samping berbagai wewenang konstitusional yang bersifat prerogatif yang lazim melekat pada jabatan kepala negara (head of state). (c) Presiden tidak bertanggung jawab kepada badan perwakilan rakyat (kongres), karena itu tidak dapat dikenai mosi tidak percaya. (d) Presiden tidak dipilih dan tidak diangkat oleh kongres, dalam praktik langsung oleh rakyat, walaupun secara formal dipilih badan pemilih (electoral college). (e) Presiden memangku jabatan empat tahun, dan hanya dapat dipilih untuk dua kali masa jabatan berturut-turut ( 8 tahun). Dalam hal mengganti jabatan Presiden yang berhalangan tetap, jabatan tersebut paling lama 10 tahun berturut-turut. (f) Presiden dapat diberhentikan dari jabatan melalui "impeachment" karena alasan tersangkut melakukan pengkhianatan, menerima suap, atau melakukan kejahatan yang serius (Bagir Manan 1999:50).

Menurut Bagir Manan, sistem presidensil di Indonesia sebelum amandemen UUD 1945, mempunyai ciri-ciri yang hampir mirip dengan sistem di Amerika Serikat dengan beberapa ciri khusus, yaitu: (a) Presiden RI dipilih oleh badan perwakilan rakyat (MPR). (b) Presiden RI tunduk dan bertanggung jawab kepada badan perwakilan rakyat (MPR), tetapi tidak tunduk dan bertanggung jawab kepada DPR. Selain itu, Presiden RI dapat diberhentikan oleh MPR. (c) Presiden RI dapat dipilih kembali tanpa batas setiap 5 tahun sekali. (d) Presiden RI bersamasama DPR menjalankan kekuasaan membentuk undang-undang (Bagir Manan 1999:59). Meskipun demikian, sistem Presidensil Pemerintahan RI berdasarkan Undang-Undang Dasar 1945 pra amandemen sifatnya tidak murni. Hal ini disebabkan sistem tersebut bercampur baur dengan elemen-elemen sistem parlementer. Percampuran itu antara lain tercermin dalam konsep pertanggung jawaban presiden kepada MPR yang termasuk ke dalam pengertian lembaga parlemen, dengan kemungkinan pemberian kewenangan kepadanya untuk memberhentikan Presiden dari jabatanya, meskipun bukan karena alasan hukum. Selain karena alasan di atas, dalam perkembangan praktek ketatanegaraan Indonesia selama ini memang selalu dirasakan adanya kelemahan-kelemahan dalam praktek penyelenggaraan sistem pemerintahan Indonesia berdasarkan UUD 1945. Karena itu, dengan empat perubahan pertama UUD 1945, khususnya dengan diadopsinya sistem pemilihan Presiden langsung, dan 
dilakukannya perubahan struktural maupun fungsional terhadap kelembagaan MPR, maka anutan sistem pemerintahan kita menjadi makin tegas menjadi sistem pemerintahan presidensil (Jimly Asshiddiqie 2005b:37).

Dipandang dari segi praktek, sistem presidensil memang memberikan beberapa keuntungan (dibanding sistem parlementer) yaitu: (1) stabilitas eksekutif yang didasarkan oleh jaminan terhadap kepastian lamanya jabatan presiden. Hal ini berbeda dengan sistem parlementer yang lebih memungkinkan terjadinya instabilitas eksekutif yang disebabkan oleh besarnya memungkinan penggunaan kekuasaan parlemen untuk menjatuhkan kabinet melalui mosi tidak percaya atau juga tanpa mosi tidak percaya secara formal ketika kabinet telah kehilangan dukungan mayoritas anggota parlemen. (2) pemilihan umum terhadap presiden dapat dianggap lebih demokratis dari pada pemilihan secara tidak langsung baik formal maupun secara informal sebagaimana eksekutif dalam sistem parlementer. (3) adanya pemisahan kekuasaan yang berarti pembatasan terhadap kekuasaan eksekutif yang merupakan proteksi yang sangat berharga untuk kebebasan individu terhadap pemerintahan (Arend Lijphart 2002:11-15).

Namun di sisi lain, sistem presidensil juga mengandung beberapa kelemahan, yaitu: (1) konflik antara parlemen dan eksekutif yang dapat menyebabkan kebuntuan (deadlock) dan kelumpuhan. Hal ini dapat saja tidak terhindarkan akibat kedudukan kedua lembaga yang samasama independen. Ketika konflik atau ketidaksepakatan terjadi, maka tidak ada institusi yang dapat menyelesaikan masalah tersebut. (2) kekakuan pemerintahan dalam batas waktu tertentu (temporal rigidity). Hal ini disebabkan oleh masa jabatan Presiden yang tetap dapat menyebabkan proses politik menjadi terhambat dan tidak menyisakan ruang untuk penyesuaian sesuai kebutuhan. (3) berlakunya sistem "the winner takes all" yang menyebabkan hanya satu kandidat dan partai yang menang, dan yang lain kalah. Selain itu, sistem ini menyebabkan Presiden akan susah untuk bernegosiasi atau berkoalisi dengan oposisi jika dalam waktu tertentu muncul masalah yang membutuhkan penyelesaian (Arend Lijphart 2002:15-19).

Dalam sistem presidensil dapat disimpulkan beberapa kewenangan Presiden yang biasa dirumuskan dalam UUD berbagai negara, yang mencakup lingkup kewenangan sebagai berikut: (1) Kewenangan yang bersifat eksekutif atau menyelenggarakan pemerintahan berdasarkan UUD (to govern based on the constitution). Bahkan dalam sistem yang lebih ketat, semua kegiatan pemerintahan yang dilakukan oleh presiden haruslah didasarkan atas perintah konstitusi dan peraturan perundang-undangan yang berlaku. Sehingga kecenderungan discretionary power dibatasi sesempit mungkin wilayahnya. (2) Kewenangan yang bersifat legislatif atau untuk mengatur kepentingan umum atau publik (to regulate public affair based on the law and the constitution). Dalam sistem pemisahan kekuasaan (separation of power), kewenangan untuk mengatur ini dianggap ada di tangan lembaga perwakilan, bukan di tangan eksekutif. Jika lembaga eksekutif merasa perlu mengatur, maka kewenangan mengatur di tangan eksekutif itu bersifat derivatif dari kewenangan legislatif. Artinya, Presiden tidak boleh menetapkan suatu peraturan yang bersifat mandiri. (3) Kewenangan yang bersifat judisial dalam rangka pemulihan keadilan yang terkait dengan putusan pengadilan, yaitu untuk mengurangi hukuman, memberikan pengampunan, ataupun menghapuskan tuntutan yang terkait erat dengan kewenangan pengadilan. Dalam sistem parlementer yang mempunyai kepala negara, ini biasanya mudah dipahami karena adanya peran simbolik yang berada di tangan kepala negara. Tetapi dalam sistem presidensil, kewenangan untuk memberikan grasi, abolisi dan amnesti itu ditentukan berada di tangan Presiden. (4) Kewenangan yang bersifat diplomatik, yaitu menjalankan perhubungan dengan negara lain atau subjek hukum internasional lainnya dalam konteks hubungan luar negeri, baik dalam keadaan perang dan damai. (5) Kewenangan yang bersifat adminstratif untuk mengangkat dan memberhentikan orang dalam jabatan-jabatan kenegaraan dan jabatan-jabatan administrasi negara. Hal ini disebabkan pula karena presiden juga merupakan kepala eksekutif. (6) Kewenangan dalam bidang keamanan, yakni untuk mengatur polisi dan angkatan bersenjata, menyelenggarakan perang, pertahanan negara, serta keamanan dalam negeri (Jimly Asshiddiqie 2005a:75-77).

\section{Sistem Presidensil di Indonesia Pasca Amandemen UUD 1945}

Konsep dan model sistem pemerintahan di atas, dapat dilakukan analisis atau perbandingan terhadap penerapan konsep dan model tersebut di dalam UUD 1945 pasca amandemen. Salah satu ketentuan yang sangat menandakan kuatnya sistem presidensil dalam 
UUD 1945 tersirat dalam Pasal 7C, yang menyatakan Presiden tidak dapat membekukan dan/atau membubarkan DPR. Secara historis, banyak pihak berpendapat bahwa pasal ini dimunculkan sebagai respon terhadap pernyataan Mantan Presiden Abdurrahman Wahid yang pernah mengeluarkan Dekrit untuk membubarkan DPR pada saat beliau menjabat sebagai Presiden RI. Namun, apabila dipandang dari segi konsep maka pasal di atas telah memenuhi salah satu persyaratan esensial dalam kultur demokrasi presidensil yaitu pemisahan kekuasaan (separation of power). Akibat dari penerapan model ini, maka baik DPR maupun Presiden tidak dapat saling membubarkan. Beberapa kondisi lain yang menandakan dianutnya sistem presidensil di Indonesia, yaitu: a. Digunakannya istilah 'Presiden' sebagai kepala pemerintahan sekaligus kepala negara. Tidak dikenal adanya pemisahan dua fungsi tersebut, sebagaimana lazimnya dalam budaya demokrasi (Jimly Asshiddiqie n.d.). b. Dianutnya prinsip pemisahan kekuasaan, sebagaimana dilihat dalam Pasal 1 ayat (2), kedaulatan berada di tangan rakyat dan dilaksanakan menurut UUD. Hal ini menandakan, tidak ada satu lembaga pun yang lebih supreme dari lembaga lainnya. Semua lembaga negara yang termasuk main organ berada dalam kedudukan yang setara dengan fungi masing-masing. c. Pemilihan Presiden dan Wakil Presiden dengan menggunakan sistem pemilihan langsung oleh rakyat, sebagaimana diatur dalam Pasal 6A. Format pemilihan umum yang terpisah antara pemilu legislatif dan Presiden dan Wapres turut menandakan dianutnya sistem presidensil. Sebab, jika pada pemilu legislatif salah satu partai menguasai kursi parlemen (meskipun tidak mayoritas), tidak otomatis menjadikan pemimpin partai tersebut menjadi seorang kepala pemerintahan. Sebagaimana lazimnya dalam budaya demokrasi parlementer. d. Kewenangan Presiden dalam legislasi yang hanya menjadi pengusul sebuah RUU kepada DPR, sebagaimana diatur dalam Pasal 5 ayat (1). Hal ini berbeda dengan format kewenangan legislasi yang sebelumnya diatur dalam UUD 1945 pra-amandemen, di mana kekuasaan legislasi pada dasarnya berada di tangan Presiden. e. Pengangkatan dan pemberhentian menteri merupakan hak prerogatif Presiden tanpa perlu mekanisme persetujuan dari DPR, sebagaimana diatur dalam Pasal 17 ayat (2). Oleh karena itu, tanggung jawab pemerintahan sepenuhnya berada di tangan Presiden. f. Penggunaan "fixed tenure of office" untuk Presiden dan Wakil Presiden yaitu 5 (lima) tahun. Hal ini dapat dilihat dalam Pasal 7. g. Lama jabatan tersebut ditegaskan pula dalam Pasal 3 ayat (3), yang menyatakan bahwa, MPR hanya dapat memberhentikan Presiden dan/atau Wakil Presiden dalam masa jabatannya menurut UUD. Yang tidak lain adalah mekanisme impeachment, sebagaimana diatur pula dalam Pasal 7A. $\mathrm{h}$. Presiden tidak bertanggung jawab kepada lembaga politik tertentu tetapi langsung kepada rakyat pemilihnya. Sebagai konsekuensi legal dan politis dari dianutnya sistem pemilihan secara langsung bagi Presiden dan Wakil Presiden. Meskipun secara praktek, Presiden pada setiap akhir tahun tetap membacakan laporan kinerja di hadapan DPR. Namun hal itu bukan merupakan mekanisme pertanggung jawaban sebagaimana eksekutif bertanggung jawab kepada parlemen dalam sistem parlementer (Jimly Asshiddiqie n.d.).

Dari beberapa kondisi di atas maka dapatlah dikatakan bahwa sistem pemerintahan yang dianut oleh UUD 1945 pasca amandemen adalah sistem presidensil murni. Tetapi, kebenaran konsep di atas hendaknya perlu diuji dalam tataran politik praktis, sebab demokrasi pada hakekatnya adalah merupakan konteks budaya politik bukan hanya konteks penafsiran dan pelaksanaan terhadap konsitusi.

Sebagaimana dikatakan oleh Richard Holder Williams bahwa, a constitution is a legal document which contains "the rules of the poli(Denny Indrayana 2008:29)tical game" (Denny Indrayana 2008:29). Selain itu, politik praktis Indonesia yang berubah secara signifikan salah satunya disebabkan oleh kemajuan dari pemahaman dan praktik konsitutisionalisme pasca amandemen UUD 1945. Hal ini sebagimana diutarakan oleh Rosen, the form in which the consitutition making process is adopted may reveal the character of the future political configuration, particularly if the process takes place during a transition from an authoritarian rule (Denny Indrayana 2008:36). Dalam hal konteks penerapan sistem presidensil di Indonesia, setidaknya ada dua hal yang menyebabkan tidak bertajinya penerapan sistem tersebut, yaitu penegasan terhadap sistem presidensil yang turut diiringi dengan penguatan peran dan wewenang parlemen dalam hubungannya dengan eksekutif, serta sistem politik yang menggunakan sistem multi partai.(Denny Indrayana 2008:36).

\section{Sistem Presidensil dengan Sistem Multipartai}


Salah satu kelemahan dalam sistem presidensil adalah sangat dimungkinkannya terjadi konflik antara parlemen dan eksekutif yang dapat menyebabkan deadlock dan kelumpuhan. Hal ini dapat saja tidak terhindarkan akibat kedudukan kedua lembaga yang masing-masing terpisah atau terbagi dan tidak bergantung satu sama lain, oleh karena itu ketika konflik atau ketidaksepakatan terjadi maka tidak ada institusi yang dapat menyelesaikan masalah tersebut. Hal ini pun dapat terjadi dalam sistem presidensil di Indonesia. Salah satu contoh termutakhir yang bisa diamati adalah ditolaknya Perpu No. 4 Tahun 2008 tentang JPSK oleh DPR yang menyebabkan penyertaan modal sementara terhadap Bank Century menjadi dipertanyakan keabsahanya. Kebuntuan terjadi akibat tidak ada mekanisme lain yang bisa ditempuh oleh presiden selain mencabut Perpu tersebut. Selain itu, sering pula terjadi percekcokan atau saling serang antara DPR dengan pemerintah, apabila hal tersebut menyangkut kebijakan tidak populis yang dilakukan pemerintah. Sebut saja kebijakan Bantuan Tunai Langsung (BLT) serta konversi minyak tanah ke elpiji yang akhirnya menimbulkan pro dan kontra. Pada akhirnya hal ini berpotensi melemahkan legitimasi dan kewibawaan Presiden di hadapan DPR selaku pengambil kebijakan (Aritonang 2010:391-407).

Berbicara mengenai demokrasi memang tidak lepas dari pada peran dan fungsi partai politik dalam sistem politik. Dengan dibukanya kesempatan yang luas kepada setiap warga negara Indonesia untuk berpartisipasi secara langsung dalam sistem politik, maka hal ini menyebabkan tumbuhnya berbagai macam jenis partai politik. Dalam sistem politik, peran partai politik sangat penting, sebagaimana dinyatakan Miriam Budiarjo, partai politik berperan sebagai: (1) Sebagai sarana komunikasi politik yang dapat digunakan sebagai ruang untuk menggabungkan dan merumuskan berbagai kepentingankepentingan (interest articulation); (2) Sebagai sarana sosialisasi politik, yakni proses untuk menyampaikan budaya politik yaitu normanorma dan nilai-nilai dari satu generasi ke generasi berikutnya; (3) Sebagai rekrutmen politik, yakni untuk memilih atau menyeleksi seorang pemimpin, baik untuk kepentingan internal maupun eksternal partai; (4) sebagai sarana pengatur konflik, yakni menekan atau mengatur konflik-konflik yang mungkin terjadi sebagai akibat sifat heterogen suatu bangsa (Huda 2010:73-79).

Banyaknya partai politik yang turut ambil bagian dalam penyelenggaraan pemilihan umum pada satu sisi memberikan dampak yang positif. Hal ini menandakan bahwa iklim demokrasi benar-benar mendapat tempat yang layak. Namun hal ini sangat berbeda jika sistem politik multi partai dihubungkan dengan pelaksanaan sistem presidensil di Indonesia. Komposisi ini sangat rentan menyebabkan kebuntuan dan perseteruan antara DPR dan eksekutif. Oleh karena itu hal ini dapat dipandang sebagai kelemahan mendasar dalam sistem presidensil Indonesia. Beberapa kelemahan tersebut antara lain: (1) Dapat menyebabkan instabilitas pemerintahan, sebab sistem presidensil memberikan kedudukan yang sama kuat kepada eksekutif dan legislatif, sehingga tidak dapat saling membubarkan. Namun sistem impeachment, sangat memungkinkan presiden dijatuhkan meskipun hal tersebut tidak serta merta terjadi pada kabinet. Dalam sistem presidensil, lobi atau negosiasi dalam proses politik menjadi sangat rigid atau tidak fleksibel, karena parlemen tidak mempunyai ikatan emosional politik yang kuat dengan presiden. (2) Dalam sistem presidensil dengan multi partai mutlak diperlukan kedisiplinan partai-partai yang berkoalisi. Sebab jika tidak maka presiden dapat kehilangan dukungan dalam parlemen. Inilah yang bisa menyebabkan kebuntuan. Ciri ini sebenarnya sangat dimiliki dalam sistem parlementer. Sebagaimana dikatakan Linz bahwa, perdana menteri dapat mengkombinasikan kekuasaannya dengan pertanggung jawaban, yang pada gilirannya membutuhkan kedisiplinan dan keutuhan dari partai-partai politik (well disciplined and strong political parties). Sebab jika tidak demikian, maka kejatuhan kabinet menjadi tidak terhindarkan. (3) Dalam sistem presidensil dengan multi partai, memang dapat dikatakan bahwa figur yang terpilih memang merupakan pilihan rakyat. Namun, hal tersebut akan kontras atau terbalik jika ternyata dalam pelaksanaan pemerintahan presiden tidak mendapatkan dukungan mayoritas suara parlemen. Meskipun pada akhirnya, DPR memang tidak dapat membubarkan kabinet namun kebuntuan dan perseteruan dapat terjadi berkepanjangan. (4) Sistem ini mengharuskan presiden untuk membuka koalisi kepada banyak partai dengan berbagai cara (Al-Arif 2015:286).

Apabila dibandingkan dengan sistem parlementer, instabilitas pemerintahan pun sebenarnya bisa terjadi dalam sistem parlementer yang berbasis multi partai. Sebagaimana dikatakan oleh Miriam Budiardjo, sistem multi partai, apalagi jika dihubungkan dengan sistem 
pemerintahan parlementer, mempunyai kecenderungan untuk menitikberatkan kekuasaan pada badan legislatif, sehingga peran badan eksekutif sering lemah dan ragu-ragu. Hal ini sering disebabkan karena tidak ada satu partai yang cukup kuat untuk membentuk suatu pemerintahan sendiri, sehingga terpaksa membentuk koalisi dengan partaipartai lain. Dalam keadaan semacam ini partai yang berkoalisi harus selalu mengadakan kemungkinan bahwa sewaktuwaktu dukungan dari partai yang duduk dalam koalisi akan ditarik kembali, sehingga mayoritas dalam parlemen hilang. Dalam kaitannya dengan sistem multi partai yang diterapkan di Indonesia, kondisi tersebut memang akan sangat berpengaruh terhadap efektivitas pelaksanaan sistem presidensil itu sendiri. Sebagai acuan, sistem presidensil Amerika Serikat menggunakan sistem dwi partai. Sehingga dapat memberikan stabilitas jangka panjang terhadap eksekutifnya. Sistem dwi partai pernah disebut sebagai a convenient sistem for contented people. Sistem ini dapat berjalan baik apabila terpenuhi tiga syarat, yaitu komposisi masyarakat bersifat homogen (social homogeneity), adanya konsensus kuat dalam masyarakat mengenai asas dan tujuan sosial dan politik (political consensus), dan adanya kontinuitas sejarah (historical continuity) (Andriyan 2016:56).

Namun sistem dwipartai juga buka tanpa kritik. Sebagaimana dikatakan oleh (1) penggunaan sistem dwipartai sebenarnya lebih merupakan bentuk "pengkambing hitaman" instabilitas pemerintahan dibanding dengan sistem multipartai. Sebab pada pengalaman beberapa negara, terbukti bahwa sistem multipartai tidak memberikan efek yang fatal yang merusak demokrasi. (2) sistem dwi-partai malah dapat mengaburkan demokrasi itu sendiri. Penggunaan sistem dwipartai memungkinkan partai-partai yang memiliki program-program yang hampir sama sehingga malah menutup akses alternatif pilihan bagi masyarakat. (3) sistem multi partai lebih memungkinkan untuk mengakomodasi pertanggungjawaban kinerja pemerintah. Sebab dalam sistem presidensil pemilihan presiden dan parlemen terpisah. (4) sistem dwi-partai lebih memungkinkan hilangnya isu-isu penting dan alternatif-alternatif program yang penting. Dalam hal ini sistem dwipartai tidak dapat mengakomodasi semua kepentingan masyarakat, sebab hanya terpecah dalam dua dimensi (left-right dimension) (Arend Lijphart 2002:111-14).

\section{Penguatan DPR Bersamaan dengan Penegasan Sistem Presidensil}

Isu utama perdebatan para perumus perubahan UUD 1945 pada perubahan pertama tahun 1999 adalah bagaimana menyempurnakan struktur ketatanegaraan yang ada. Begitu kompleks dan banyaknya persoalan yang disampaikan dalam perdebatan awal itu, maka perubahan yang disepakati pada perubahan pertama ini adalah bagaimana mengurangi dan membatasi kekuasaan Presiden dan memperkuat posisi DPR sebagai lembaga negara yang memiliki kekuasaan membentuk undang- undang (Sumarandak 2019:36-41).

Perubahan selanjutnya terhadap DPR adalah pada fungsi pengawasannya yang dalam UUD 1945 sebelum perubahan hanya disinggung dalam bagian penjelasan. Karena fungsi pengawasan ini dianggap penting dimiliki oleh DPR untuk berjalannya mekanisme kontrol terhadap eksekutif, maka ketentuan dalam penjelasan UUD 1945 itu dimuat secara tegas dalam pasal-pasal UUD 1945 secara lebih jelas dan rinci. Pasal 20 ayat 1, mempertegas tiga fungsi yang dimiliki oleh DPR, yaitu fungsi legislasi, fungsi anggaran, dan fungsi pengawasan. Oleh karena itu, hubungan parlemen dan eksekutif dalam sistem presidensil Indonesia pasca amandemen UUD 1945, setidaknya dapat dilihat dalam tiga konteks, yaitu: (a) Penguatan peran dan kewenangan DPR setelah amandemen UUD 1945. (b) Penegasan fungsi dan hak yang dimiliki DPR sebagai lembaga pengawas eksekutif. (c) Penegasan check and balances sistem parlemen dan eksekutif. Dalam hal ini, amandemen UUD 1945 tidak hanya memberikan penegasan saja kepada sistem presidensil di Indonesia, tetapi juga mengembalikan kewibawaan parlemen sesuai fungsi utamanya. Penguatan kelembagaan tersebut akhirnya memberikan pandangan bahwa, perubahan UUD 1945 telah menyiratkan peralihan dari yang semula sistem presidensil sistem executive heavy kepada sistem presidensil legislative heavy, sehingga lebih menegaskan supremasi parlemen terhadap eksekutif. Ini terlihat dari kekuasaan legislatif yang sangat luas mulai dari pembuatan undang-undang sampai wewenang kontrol. Selain itu pengangkatan pimpinan dan anggota komisi-komisi atau badan-badan independen serta duta besar harus melalui pemilihan dan pengujian di DPR. Amandemen terhadap kedudukan dan fungsi DPR sebagai parlemen atau badan legislatif memang mutlak dilakukan. Sebab UUD 1945 sebelum 
amademen memang mengandung banyak kelemahan mendasar, yang diantaranya, adalah:(Arliman 2019:77-89).

(1) UUD 1945 membangun sistem politik yang executive heavy dengan memberikan porsi yang sangat besar kepada kekuasaan presiden tanpa adanya mekanisme check and balances yang memadai. (2) UUD 1945 terlalu banyak memberikan atribusi dan delegasi kewenangan kepada presiden untuk mengatur lagi hal-hal penting dengan undang-undang maupun dengan peraturan pemerintah. (3) UUD 1945 memuat beberapa pasal yang ambigu atau multi tafsir sehingga bisa ditafsirkan dengan bermacam-macam tafsir, tetapi tafsir yang harus diterima adalah tafsir yang dibuat presiden. (4) UUD 1945 lebih mengutamakan semangat penyelenggaraan negara dari pada sistemnya. Sebagai lembaga legislatif atau parlemen, DPR sendiri mempunyai beberapa fungsi (Arliman 2019:77-89).

Fungsi-fungsi tersebut mengandung hak-hak yang akan dimiliki oleh parlemen sebagai individu atau kelembagaan untuk mengawasi kinerja (performance) pemerintah. Fungsi-fungsi tersebut, yaitu: (a) Fungsi legislasi, yakni menentukan kebijakan (policy) dan membuat undangundang. Untuk itu lembaga parlemen diberi hak inisiatif, hak untuk mengadakan amandemen terhadap rancangan undang-undang yang disusun oleh pemerintah, terutama dibidang budget atau anggaran. Fungsi ini jelas tertuang dalam Pasal 20 ayat 1, yang menyatakan bahwa, DPR memegang kekuasaan membentuk undang-undang. Meskipun pelaksanaan wewenang ini tidak dapat dilaksanakan sendiri atau sepihak oleh DPR sebab pembahasan sebuah undang-undang harus dilaku- kan bersama-sama dengan Presiden dan DPD (dalam hal tertentu). Saldi Isra bahkan menyatakan bahwa, tidak tepat jika dikatakan kewenangan pembentukan undangundang sepenuhnya berada di tangan DPR, sebab dalam hal ini Presiden tetap mempunyai kewenangan dalam legislasi (bagian dari legislasi) meskipun hanya untuk mengajukan RUU (Saldi Isra 2010:318).

Selain itu pembahasam dan persetujuan terhadap undang- undang harus dilakukan bersama-sama. (b) Fungsi pengawasan (control), yakni mengontrol badan eksekutif dalam arti menjaga agar semua tindakan badan eksekutif sesuai dengan kebijakan-kebijakan yang telah ditetapkan (oversight). Untuk menyelenggarkan tugas ini lembaga parlemen diberi hak-hak kontrol khusus, seperti hak bertanya, interpelasi, angket, dan mosi (dalam sistem parlementer). Fungsi Pengawasan beserta hak-haknya, tertuang di dalam pasal 20 A. Ruang lingkup pengawasan DPR terhadap eksekutif termasuk didalamnya, pengawasan terhadap pengelolaan APBN, pembentukan dan pelaksanaan kebijakan eksekutif, beserta tindakantindakan lain dari pemerintah. (c) Fungsi perwakilan (representasi), yakni merupakan fungsi yang paling pokok. Dalam hal ini dibedakan dalam dua pengertian perwakilan yaitu perwakilan secara fisik dan perwakilan secara pemikiran atau ide (Jimly Asshiddiqie 2007:165).

Fungsi Perwakilan sendiri secara tersirat tertuang dalam Pasal 19 ayat (1), yang menyatakan bahwa anggota DPR dipilih melalui pemilihan umum. Dari pasal ini dapat disimpulkan, DPR pada hakikatnya adalah penjelmaan dari seluruh kepentingan rakyat. (d) Fungsi lainnya, yakni seperti mengesahkan (ratify) perjanjian-perjanjian internasional yang dibuat oleh badan eksekutif, wewenangan untuk menuntut (impeach) dan mengadili pejabat tinggi, termasuk presiden. Fungsi ratifikasi, dengan jelas tertuang dalam Pasal 11 ayat (1) UUD 1945 bahwa Presiden dengan persetujuan DPR menyatakan perang, membuat perdamaian, dan perjanjian dengan negara lain.(Pitoy 2014:28-37).

\section{KESIMPULAN}

Amandemen terhadap UUD 1945 telah menegaskan bahwa sistem pemerintahan yang dianut adalah sistem pemerintahan presidensil. Hal ini merupakan salah satu tindakan perbaikan atau korektif terhadap sistem presidensil yang lama sebelum UUD 1945 diamandemen. Sistem yang lama melahirkan banyak kelemahan dalam pelaksanaan check and balances system. Selain itu terlihat bahwa UUD 1945 sebelum amandemen memberikan banyak kewenangan kepada eksekutif, sehingga bersifat executive heavy. Selain penegasan terhadap sistem presidensil, perubahan ketatanegaraan juga memberikan penguatan terhadap peran dan kedudukan DPR. UUD 1945 amandemen menegaskan fungsi-fungsi dan hak-hak DPR sebagai lembaga legislatif dan pengawas kinerja pemerintah. Pelaksanaan fungsi-fungsi dan hak-hak ini 
merupakan hal yang mutlak sebagai bagian dari penyempurnaan check and balances system. Namun ternyata, amandemen UUD 1945 malah menggeser kedudukan DPR ke arah yang lebih kuat, sehingga lebih bersifat legislative heavy. Sehingga hampir semua hal yang menjadi kewenangan eksekutif pada prakteknya harus mendapatkan persetujuan dari DPR. Kondisi berikutnya yang mewarnai pelaksanaan sistem presidensil Indonesia adalah dengan digunakannya format multi partai dalam sistem politik Indonesia. Dipandang dari sisi demokrasi, penggunaan sistem multi partai memang memberikan kesempatan yang luas kepada setiap orang untuk ambil bagian dalam pelaksanaan hak-hak politiknya. Namun dipandang efektivitas penyelenggaraan pemerintahan, sistem ini malah memperlemah pelaksanaan sistem presidensil. Pertaruhan politik antara DPR dan Presiden kerap menyebabkan pertentangan antara kedua lembaga negara tersebut. Akibatnya, penyelenggaraan pemerintahan lebih banyak diwarnai persoalan politik dari pada realisasi kebijakan pemerintah terhadap masyarakat.

\section{REFERENSI}

Al-Arif, M. Yasin. 2015. “Anomali Sistem Pemerintahan Presidensial Pasca Amandemen UUD 1945." Jurnal Hukum Ius Quia Iustum 22(2):238-54.

Andriyan, Dody Nur. 2016. Hukum Tata Negara Dan Sistem Politik: Kombinasi Presidensial Dengan Multipartai Di Indonesia. Deepublish.

Arend Lijphart. 2002. Parliamentary versus Presidential Government. New York: Oxford University Press.

Aritonang, Dinoroy Marganda. 2010. "Penerapan Sistem Presidensil Di Indonesia Pasca Amandemen UUD 1945." Mimbar Hukum-Fakultas Hukum Universitas Gadjah Mada 22(2):391-407.

Arliman, Laurensius. 2019. "Penyelenggaraan Sistem Presidensil Berdasarkan Konstitusi Yang Pernah Berlaku Di Indonesia." Jurnal Muhakkamah 4(2):77-89.

Bagir Manan. 1999. Lembaga Kepresidenan. Yogyakarta: Gama Media.

Denny Indrayana. 2008. Indonesian Contitutional Reform 1999-2002 an Evaluation of Constitution Making in Transition. Jakarta: Kompas.

Huda, Ni'matul. 2010. “Pengujian Perppu Oleh Mahkamah Konstitusi.” Jurnal Konstitusi 7(5):7392.

Jimly Asshiddiqie. 2005a. Format Kelembagaan Negara Dan Pergeseran Kekuasaan Dalam UUD 1945. Yogyakarta: FH UII.

Jimly Asshiddiqie. 2005b. Implikasi Perubahan UUD 1945 Terhadap Pembangunan Hukum Nasional. Jakarta: Mahkamah Konsitusi RI.

Jimly Asshiddiqie. 2007. Pokok-Pokok Hukum Tata Negara Pasca Reformasi. Jakarta: Bhuana Ilmu Populer.

Jimly Asshiddiqie. n.d. "Jimly School of Law and Government." Retrieved March 6, 2021 (https://www.jimlyschool.com/).

Joeniarto. 1982. Demokrasi Dan Sistem Pemerintahan Negara. Yogyakarta: Bina Aksara.

Miriam Budardjo. 2009. Dasar-Dasar Ilmu Politik. Jakarta: Gramedia Pustaka Utama. 
Pitoy, Hezky Fernando. 2014. "Mekanisme Checks and Balances Antara Presiden Dan Dpr Dalam Sistem Pemerintahan Presidensial Di Indonesia." Lex et Societatis 2(5).

Sa'adah, Nabitatus. n.d. "Persoalan Yang Tersisa Dalam Sistem Presidensiil Pasca Amandemen Uud 1945." Masalah-Masalah Hukum 48(3):275-82.

Saldi Isra. 2010. Pergeseran Fungsi Legislasi Dalam Sistem Pemerintahan Indonesia Setelah Perubahan UUD 1945. Yogyakarta: Fakultas Hukum UGM.

Sumarandak, Widya Christie. 2019. "Kewenangan Presiden Republik Indonesia Di Bidang Legislatif Setelah Perubahan Undang-Undang Dasar Negara Republik Indonesia Tahun 1945." LEX ADMINISTRATUM 6(4).

Yani, Ahmad. 2018. "Sistem Pemerintahan Indonesia: Pendekatan Teori Dan Praktik." Jember: Jurnal Lentera Hukum University of Jember 5(2). 